\title{
Transcriptomic analysis of differential gene expression reveals an increase in COX2 levels during in vitro canine herpesvirus infection
}

\author{
Jacqueline Kazue Kurissio $^{1^{*}}$ (ค) João Pessoa Araújo Júnior ${ }^{1}$ \\ ${ }^{1}$ Departamento de Microbiologia e Imunologia, Instituto de Biociências, Instituto de Biotecnologia, Faculdade de Medicina Veterinária e \\ Zootecnia (FMVZ), Universidade Estadual Paulista (UNESP), Botucatu, 18618-691, SP, Brasil. E-mail: jkkurissio@yahoo.com.br. \\ *Corresponding author.
}

\begin{abstract}
Canine herpesvirus (CaHV-1) affects canids worldwide, causing death in neonates and immunosuppressed hosts. Acute infection by CaHV-1 can cause reproductive, respiratory, and neurological problems in adult animals. Viral pathogenesis and host genes expressions during of CaHV-1infection are not clearly understood. In the present study, the transcriptome of canine kidney cell Mardin-Darby $(M D C K)$ infected in vitro with canine herpesvirus was explored. For this, RNA sequencing (RNA-seq) of the samples in different moments during infection was carried out. Subsequently, the transcriptomic analysis genes related to cell activities and process involved to viral cycle infection were evaluated until $32 \mathrm{~h}$ post-inoculation (pi). Among evaluated genes, was verified a significant and gradative increase of the prostaglandin-endoperoxide synthase 2 (PTGS2) or cyclooxygenase 2 (COX2) gene expression, throughout of infection, though differential gene expression analysis and validated by quantitative reverse transcription PCR (RT-qPCR). High COX2 expression is usually induced in response to inflammation, pathogens or activation of the immune system but can be a viral mechanism to favor viral replication. Thus, COX2 level increase can be a favorable factor for viral infection with Cahv-1 virus and the use of selective COX2 inhibitors may be beneficial for limiting the infection or clinical signs by causing interruption of the viral replication cycle during active infection. Additionally, the regulation genes expression differential verified in this study can contribute to determining important targets for inhibiting canine herpesvirus infection either by cellular or viral mechanisms.
\end{abstract}

Key words: transcriptome, herpesvirus, CaHV-1, PTGS2, COX2, canine pathogen.

Análise transcriptômica da expressão gênica diferencial revela um aumento nos níveis de COX2 durante a infecção in vitro por herpesvirus canino

RESUMO: O herpesvírus canino (CaHV-1) afeta os canideos em todo o mundo, causando morte em neonatos e hospedeiros imunossuprimidos. A infecção aguda por CaHV-1 pode causar problemas reprodutivos, respiratórios e neurológicos em animais adultos. A patogênese viral e expressão de genes hospedeiros durante a infecção por CaHV-1 ainda não são bem compreendidos. No presente estudo, o transcriptoma de células de rim canino Madin-Darby (MDCK) infectadas in vitro com herpesvirus canino foi explorado. Para isso, foi realizado o sequenciamento de RNA (RNA-seq) de amostras coletadas em diferentes momentos durante a infecção. Subsequentemente, a análise transcriptômica dos genes relacionados à atividade celular e aos processos envolvidos no ciclo de infecção do vírus foram avaliadas até 32 horas após a inoculação (pi). Dentre os genes avaliados, constatamos uma elevação significativa e gradativa da expressão da Prostaglandina-endoperoxide sintase 2 (PTGS2) ou ciclooxigenase 2 (COX2), ao longo da infecção viral, foi verificada por análise de expressão gênica diferencial e validada por resultados de transcrição reversa por PCR quantitativo (RT-qPCR). O aumento da expressão de COX2 geralmente é induzida em resposta a inflamação, patógenos ou ativação do sistema imune, mas também pode ser um mecanismo para favorecer a replicação viral. Assim, o aumento do nível de COX2 pode ser um fator favorável à infecção viral pelo vírus CaHV-1 e o uso de inibidores seletivos da COX2 pode ser benéfico para limitar a infecção ou os sinais clínicos, causando a interrupção do ciclo de replicação viral durante a infecção ativa. Além disso, a regulação diferencial da expressão dos genes verificados neste estudo podem contribuir para determinar alvos importantes para inibir a infecção por herpesvírus canino, seja por mecanismos celulares ou virais.

Palavras-chave: transcriptome, RNA-seq, herpesvírus, CaHV-1, COX2, patógeno.

\section{INTRODUCTION}

The canine herpesvirus causes a contagious viral infection among canids in many countries (ROBINSON et al., 2005; RONSSE et al., 2005). Etiological agent of canine herpesvirus belongs to the species Canine alphaherpesvirus 1 (CaHV-1), genus Varicellovirus, subfamily Alphaherpesvirinae, and family Herpesviridae (ICTV 2017). It is a virus in which double-stranded DNA is contained in a nucleocapsid, immersed in the tegument, and enclosed into a lipoprotein envelope (DAVISON et al., 2009). Naturally infected dogs with CaHV-1 represent an economic loss to breeding kennels due to 
reproductive, respiratory, and neurologic problems, and death by systemic disease in immunosuppressed adults and neonates (MALONE et al., 2010; EVERMANN et al., 2011; LARSEN et al., 2015). However, the pathogenesis of canine herpesvirus infection is not well known. The inactivated subunit vaccine against CaHV-1 is available in Europe, where it is used on breeding females, conferring short-duration passive immunity (CARMICHAEL \& GREENE, 2012).

Herpesviruses are ubiquitous pathogens, well adapted to their hosts through many regulation mechanisms related to viral replication and cellular process domains (HOULDCROFT \& BREUER, 2015; WEI et al., 2016). During productive infection, herpesviruses establish a complex and robust standard for viral genic expression (JURAK et al., 2011). Additionally, host response to viral infections involves intricate sets of regulatory processes (LAN et al., 2018). Therefore, the herpesviruses develop a mechanism to ensure the efficient translation of both viral and cell mRNA (GALE JR et al., 2000). The expression of the gene encoding prostaglandinendoperoxide synthase 2 (PTGS2), better known as cyclooxygenase 2 (COX2), is induced by inflammatory response and infections, including those caused by viruses, in which COX products and derivatives may play a role in host response (KIRKBY et al., 2011; KUNZMANN et al., 2013). COX2 is involved in the production of prostanoids, which contribute to vasodilation, leukocyte chemotaxis, fever, and potential nociception (KIRKBY et al., 2011). However, during herpesvirus infection, the transcription of COX2 is essential for viral replication and virus-host interaction (RAY \& ENQUIST, 2004). Under resting conditions, COX2 mRNA is not expressed by most cells (PABLOS et al., 1999).

Transcriptomic analysis is essential to study functional genome elements, subjacent mechanisms and disease triggers (YANG \& KIM, 2015). RNAsequencing (RNA-seq) using the next generation sequencing (NGS) platform has enabled the analysis of millions of transcripts from biological samples (MUTZ et al., 2014). Furthermore, RNA-seq is considered the gold standard for whole transcriptome gene expression quantification (EVERAERT et al., 2017). Thus, through transcriptional profile analysis, information on the biology of cells during certain conditions, as well as mechanisms and cell response to viral infection, can be obtained (WANG et al., 2009). Therefore, the purpose of this study was to analyze differential cellular gene expression during CaHV-1 infection in vitro. Additionally, the levels of COX2 expression in response to viral replication were evaluated. To our knowledge, this is the first transcriptomic analysis of $\mathrm{CaHV}-1$ infection in vitro using RNA-seq.

\section{MATERIALS AND METHODS}

\section{Cell culture and viral infection}

For viral infection, a viral suspension of CaHV-1 strain BTU-1 $\left(10^{6.1}\right.$ TCID $\left._{50}\right)$ was obtained from the kidney of an infected neonatal puppy that died of a systemic infection. The genomic sequence of CaHV-1 strain BTU-1 was deposited in GenBank (KT828242). Subsequently, MDCK cells were subcultured in a 24-well plate in Dulbecco's modified Eagle medium (DMEM) and 10\% fetal bovine serum (FBS), and maintained at $37^{\circ} \mathrm{C}$ in the presence of $5 \% \mathrm{CO}_{2}$ and $80 \%$ humidity. After incubation for $24 \mathrm{~h}$, when $90 \%$ monolayer confluence was achieved, containing approximately $9.24 \times 10^{5}$ cells/well. Cells were infected with $\mathrm{CaHV}-1$ at a multiplicity of infection (MOI) of 3 . Next, the cell culture plate and viral suspension were maintained at $4^{\circ} \mathrm{C}$ for $1 \mathrm{~h}$ to allow the adsorption and synchronization of the infection, as described by FLORES \& KREUTZ, 2012. Next, the cell monolayer was washed three consecutive times with sterile phosphate-buffered saline (PBS) solution $\left(0.01 \mathrm{M} \mathrm{PO}_{2}^{-4}, 0.14 \mathrm{M} \mathrm{NaCl}\right.$, $\mathrm{pH}$ 7.4). Finally, DMEM containing $1 \% \mathrm{FBS}$ was added, and the cells were incubated at $37^{\circ} \mathrm{C}$, under conditions of $5 \% \mathrm{CO}_{2}$ and $80 \%$ humidity atmosphere. Nucleic acid extraction from cells was performed at different time periods after infection in duplicate.

\section{Isolation of nucleic acids \\ For RNA extraction, the Total RNA} Purification Kit (Norgen Biotek Corp.) was used according to the manufacturer's instructions. RNA samples were evaluated for purity by spectrophotometry using a Nanodrop ND1000 (Thermo Scientific), and the concentration was measured by fluorimetry using a Qubit 2.0 Fluorometer (Invitrogen Corp.). The integrity and quality of the RNA were analyzed using a Bioanalyzer 2100 (Agilent Technologies); a RNA integrity number (RIN) above 8.0 was considered acceptable. DNA extraction was performed using a Thermo Scientific GeneJET Genomic DNA Purification Kit (Thermo Fischer Scientific Inc.), following the manufacturer's instructions.

\section{Sequencing libraries}

Samples for sequencing libraries were prepared using the Sure Select Strand-specific RNA 
Library Prep reagents of the Illumina ${ }^{\circledR}$ Multiplexed Sequencing mRNA library kit (Agilent Technologies), following the manufacturer's instructions. Specifically, duplicate samples collected at pre-inoculation, $0 \mathrm{~h}$ (postadsorption), $1 \mathrm{~h}$ post-inoculation (pi), $4 \mathrm{~h} \mathrm{pi}, 16 \mathrm{~h} \mathrm{pi,} 20 \mathrm{~h}$ pi, 24h pi, 28h pi, and $32 \mathrm{~h}$ pi were used. Quantification of the sample libraries was performed based on the absolute standard curve of the quantitative polymerase chain reaction (qPCR), using the Kapa Library Quantification Kit Illumina ${ }^{\circledR}$ platform (Kapa Biosystem Inc.), following the manufacturer's instructions. Amplification reaction of the library fragments was performed using an $\mathrm{AB} 7500$ Fast thermal cycler (Applied Biosystem). After quantification, each sample library was normalized to $0.5 \mathrm{nM}$ to prepare a library pool. Capillary electrophoresis was performed using a Qiaxel Advanced System (Qiagen Company) to evaluate the presence of dimers and estimate the fragment length of the libraries. Additionally, the qPCR products were loaded onto an agarose gel (1.5\%), stained with Neotaq Brilliant Plus DNA Stain (NeoBio) at $0.5 \mu \mathrm{L} / \mathrm{mL}$, and electrophoresed. Gel bands were observed under ultraviolet light using a Fluor Chem FC2 Imaging system (Alpha Innotech Corp.) and analyzed using the Alpha View Program version 3.2.2 (Cell Biosciences Inc.).

\section{Clustering and sequencing}

For sequencing of mRNA libraries, the High Output Kit for up to 400M cluster - V2 75 cycles (Illumina) was used; sequencing was performed on the Illumina Next seq 500/550 platform (Illumina) for single-end and 75-bp sequences.

\section{Differential expression analysis}

The sequences obtained by RNA-seq were analyzed using the CLC Genomics Workbench 7.0.4 software (CLC Bio, Qiagen Company). Sequences were cleaned with a quality index limit of 0.08 and maximum limit of 2 ambiguous nucleotides and fragments above 40bp. In addition, the analysis of the components of differentially expressed genes (DEGs) reported in each library was performed. Sequence reads were analyzed with the RNA-seq software on the CLC platform, and mapped onto the mRNAs of the Canis lupus familiaris genome. Expression levels were assessed using the RPKM (reads per kilobase million mapped reads) as a method of analysis, and submitted to quantile normalization (ROBINSON \& SMYTH, 2008). Next, transformed into $\log 2$ expression values for subsequent statistical analysis. The Kal test (Z-Test) was employed to identify differentially expressed transcripts (KAL et al., 1999). In DEG analysis, data filtering at least two fold-change (FC) values $(>2$ and $<-2$ ), P-values $<0.05$, a false positive rate (FPR) $<0.05$, and RPKM values $\geq 2$ were used.

\section{Functional enrichment analysis based on gene ontology}

Enrichment analysis was performed for differentially expressed transcripts using an $\mathrm{FC}$ value greater than 2 across the Gene Ontology Database released by the Gene Ontology Consortium (GOC; $<\mathrm{http}$ ://www.geneontology.org $>$.

\section{Reverse transcription (RT)-qPCR for COX2 gene expression validation}

Total RNAs were isolated from cells at various times after viral infection (pre-inoculation, 0h, 1h, 4h, 16h, 20h, 24h, 28h, and 32h) using the Total RNA Purification Kit (NorgenBiotek Corp.). The samples were incubated with deoxyribonuclease I (Invitrogen Corp.) to remove residual DNA.RTqPCR experiments were carried out on a 7500 Fast Real-Time PCR System (Applied Biosystem) using Go Script Reverse Transcriptase reagents (Promega), $0.2 \mu \mathrm{L}$ of each primer $(10 \mu \mathrm{M})$, and nuclease-free water q.s.p.to achieve a final reaction volume of $20 \mu \mathrm{L}$. Reverse transcription was performed at $45^{\circ} \mathrm{C}$ for $10 \mathrm{~min}$, followed by reverse transcriptase inactivation and Taq polymerase activation at $95^{\circ} \mathrm{C}$ for $2 \mathrm{~min}, 40$ cycles at $95^{\circ} \mathrm{C}$ for $10 \mathrm{~s}$, and $60^{\circ} \mathrm{C}$ for 30s. Primers used for COX2 target amplification were based on CLEMENTE et al. (2013). Glyceraldehyde3-phosphate dehydrogenase (GAPDH) was used as the reference gene, and the sequence primers were based on those used in a study by PARK et al. (2013). Normalization of the COX2 expression data was performed to canine GAPDH, according to a previously published method (LARIONOV et al., 2005). The expression FC value was calculated using the $2^{-\Delta \Lambda \mathrm{Ct}}$ method, according to LIVAK \& SCHIMITTGEN (2001).

Construction of the plasmid standards for the qPCR assay

Afragment of the TK gene (494bp) was used as the CaHV-1 standard DNA, with an external primer set described by SCHULZE and BAUMGARTNER (1998). This fragment sequence was cloned into the pGEM-T Easy Vector plasmid (Promega), according to the manufacturer's instructions. Escherichia coli JM109 was used as the cloning strain. The recombinant plasmids were purified using E.Z.N.A Plasmid Mini Kit (Omega Bio-tek), and quantified by fluorimetry using the Qubit $^{\circledR}$ Quantification System (Invitrogen 
Corp.). For preparing the absolute standard curve, the recombinant plasmid DNA containing CaHV$1 \mathrm{TK}$ region was serially diluted 10 -fold, i.e. dilutions ranging from $10^{-1}$ to $10^{-10}$ were prepared in nucleasefree water. Aliquots $(2 \mu \mathrm{L})$ of the diluted plasmid were used in duplicate in the qPCR for the amplification of TK using the internal primer set, as described by SCHULZE \& BAUMGARTNER (1998).

\section{Estimation of the viral load during in vitro} infection by qPCR

Samples of the infected cells were collected in duplicate to perform DNA extraction for the determination of the viral load at the following infection times: $0 \mathrm{~h}, 1 \mathrm{~h}$ pi, $4 \mathrm{~h}$ pi, $16 \mathrm{~h}$ pi, $20 \mathrm{~h} \mathrm{pi}, 24 \mathrm{~h}$ pi, $28 \mathrm{~h}$ pi, and $32 \mathrm{~h}$ pi. The mixture for the qPCR was prepared using the master mix qPCR Gotaq Sybr Green (Promega), $0.4 \mu \mathrm{L}$ of each primer $(0.01 \mu \mathrm{M})$, $2 \mu \mathrm{L}$ of sample DNA, and nuclease-free water q.s.p, to achieve a final reaction volume of $20 \mu \mathrm{L}$. Amplification of $T K$ was conducted using the thermocycler $\mathrm{AB}$ 7500 Fast (Applied Biosystem) under the following conditions: $95^{\circ} \mathrm{C}$ for $2 \mathrm{~min}, 40$ cycles at $95^{\circ} \mathrm{C}$ for $15 \mathrm{~s}$, $57^{\circ} \mathrm{C}$ for $10 \mathrm{~s}$, and $72^{\circ} \mathrm{C}$ for $30 \mathrm{~s}$. The amplification run contained control reactions. The negative control contained DNA extracted from uninfected MDCK cells, whereas the positive control contained the DNA extracted from CaHV-1 stocks. Nuclease-free water was used instead of DNA as the reaction control.

\section{RESULTS AND DISCUSSION}

\section{Analysis of differentially expressed genes}

After filtering and treatment of the sequences for the analysis of DEGs, RNA-seq generated 164.81 million reads, which were mapped to the canine genome to yield 124.02 million reads, which were analyzed by CLC Genomics Workbench 7.0.4 software. Of the 2,999 DEGs identified 1,662 were positively regulated and 1,335 were negatively regulated.

The collection times were initially selected to evaluate the cycle of infection of the virus in the cell, being $1 \mathrm{~h}$ and $4 \mathrm{~h}$ pi to evaluate the virus entry into the cell. Viral replication was evaluated at $16 \mathrm{~h}$ pi. At $20 \mathrm{~h} \mathrm{pi}$, it was evaluated the onset of cytopathic effects in infected cells and then monitored until $32 \mathrm{~h}$ to evaluate the possible effects of cytolysis and apoptosis.

Cell genes expressed most up-regulated verified during in vitro CaHV-1 infection are shown in table 1 . Among them, were verified genes associated with apoptosis or cell cycle arrest, cell proliferation and immune response. The genes with higher expression levels throughout the course of the infection were EGR-1 ( $1 \mathrm{~h} \mathrm{pi,} \mathrm{FC}=35.30 \pm 5.52)$, FOS (1h pi, FC=33.38 \pm 0.89 ), and COX2 (32h pi; $\mathrm{FC}=26.41 \pm 0.74)$. Thus, EGR-1 and FOS well as well DUSP-1, are important in response to the immune system to infection, including virus (BAHRAMI \& DRABLØS, 2016). However, EGR-1 can increase viral replication by activating promoters of viral productive cycle genes and suppressing the promoter of the latent gene (CHEN et al., 2009). In a previous transcriptomic analysis, PAULUS et al. (2016) verified that the expression of FOS and DUSP-1 was activated by immediate stress response in cells infected with Suid alphaherpesvirus 1 (more commonly known as pseudorabies virus or Aujeszky's disease virus). Therefore, in the early stages of the viral infection, the highest expression of cellular immediate early genes (IEGs) was verified. IEGs are genes that encoding the first phase of mRNAs expressed from the viral genome of pre-existing host cell proteins (TINDALL and CLERK, 2014). Additionally, IEGs are expressed rapidly and transiently, induced in cells by mitogenic factors due to changes in the physiological state, stress and pathogens (RAHAUS \& WOLFF, 2003; PRADO \& DEL BEL, 1998). The ATF3 (activating transcription factor) is an IEG and designated as a stress-inducible gene (LU et al., 2006). The induction transcriptional mechanism of ATF3 by DNA damage response is rapid and transient (FAN et al., 2002). Thus, at $1 \mathrm{~h}$ pi the ATF3 was up-regulated $(\mathrm{FC}=8.86 \pm 0.81)$, but at $32 \mathrm{~h}$ pi it expression was noted as being 2.3 times higher $(\mathrm{FC}=20.37 \pm 2.24)$ than at $1 \mathrm{~h}$ pi. Thus, ATF3 late expression may play a role as proapoptotic gene being induced by pro inflammatory cytokines and hypoxia (ZHANGA et al., 2002; LU et al., 2006). Table 2 contains the 20 major inhibited cell genes during CaHV-1 infection in MDCK cell. Most of the genes were associated with inhibition of maintenance or structure cell while the remainder were associated with cell regulation cycle or apoptosis and immune. Thus, the virus interact with cell cycle regulatory and rapidly shuts off cellular protein synthesis, dampening host responses to infection and allowing viral mRNAs to dominate translational machinery (FLEMINGTON, 2001; SMILEY, 2004). The most inhibited gene, ENSCAFG00000004590 (PTHR11143) which encodes the 60S ribosomal protein L26 (RPL26) family, showed the maximum inhibition at time $24 \mathrm{~h}$ pi $(\mathrm{FC}=-236.25)$. In cells subjected to DNA damage or stress, RPL26 binds to the mRNA responsible for inducing the translation of the $\mathrm{p} 53$ protein, thus leading to cellular halt response or apoptosis (KASTAN \& BARTEK, 2004). However, 
Transcriptomic analysis of differential gene expression reveals an increase in COX2 levels during in vitro canine herpesvirus infection. 5

Table 1 - List of 20 most up-regulated genes during in vitro CaHV-1 infection as a function of time (H) and quantity (FC).

\begin{tabular}{|c|c|c|c|c|}
\hline Gene Symbol & Description & Gene product function & Time & $\mathrm{FC}$ \\
\hline 1. EGR-1 & Early growth response protein 1 & Transcriptional regulator & $1 \mathrm{~h}$ & 35.30 \\
\hline 2. FOS & Proto-oncogene c-Fos & Essential for cell proliferation and differentiation & $1 \mathrm{~h}$ & 33.38 \\
\hline 3. $\mathrm{COX} 2$ & Prostaglandin $\mathrm{g} / \mathrm{h}$ synthase 2 & $\begin{array}{l}\text { Increase cell adhesion, phenotypic changes, } \\
\text { resistance to apoptosis and tumor angiogenesis }\end{array}$ & $32 \mathrm{~h}$ & 26.41 \\
\hline 4. CHAC1 & $\begin{array}{l}\text { Cha C glutathione specific gamma- } \\
\text { glutamylcyclotransferase } 1\end{array}$ & Pro-apoptotic component & $32 \mathrm{~h}$ & 24.74 \\
\hline 5. DDIT4 & DNA damage-inducible transcript 4 protein & $\begin{array}{c}\text { Responses to cellular energy levels and cellular } \\
\text { stress, including responses to hypoxia and DNA } \\
\text { damage. }\end{array}$ & $32 \mathrm{~h}$ & 20.83 \\
\hline 6. ATF3 & $\begin{array}{l}\text { Cyclic amp-dependent transcription factor } \\
\qquad \text { ATF-3 }\end{array}$ & $\begin{array}{l}\text { This protein binds the camp response element } \\
\text { (CRE), present in many viral and cellular } \\
\text { promoters, repressor of inflammatory response }\end{array}$ & $32 \mathrm{~h}$ & 20.37 \\
\hline 7. ISG20 & Interferon stimulated exonuclease gene 20 & Interferon-induced antiviral exoribonuclease & $32 \mathrm{~h}$ & 12.75 \\
\hline 8. BTG2 & BTG anti-proliferation factor2 & Anti-proliferative protein & $32 \mathrm{~h}$ & 11.44 \\
\hline 9. RPL4 & RPL4 ribosomalprotein L4 & $\begin{array}{l}\text { Compose a large ribonucleoprotein complex } \\
\text { responsible for the synthesis of proteins in the cell }\end{array}$ & $1 \mathrm{~h}$ & 11.13 \\
\hline 10. DUSP1 & Dual specificity protein phosphatase 1 & Cellular response to environmental stress & $1 \mathrm{~h}$ & 10.79 \\
\hline 11. MARCKSL1 & MARCKS like1 & $\begin{array}{l}\text { Controls cell movement by regulating actin } \\
\text { cytoskeleton homeostasis }\end{array}$ & $32 \mathrm{~h}$ & 9.79 \\
\hline 12. TNFAIP3 & TNF alpha inducedprotein3 & $\begin{array}{l}\text { Involved in the cytokine-mediated immune and } \\
\text { inflammatory responses. }\end{array}$ & $32 \mathrm{~h}$ & 9.52 \\
\hline 13. SON & Protein SON & $\begin{array}{l}\text { DNA-binding, tumorigenesis and apoptosis, but } \\
\text { functional significance of this protein had not been } \\
\text { recognized. }\end{array}$ & $16 \mathrm{~h}$ & 9.42 \\
\hline 14. MRPL33_1 & Mitochondrial ribosomal protein L33 & $\begin{array}{l}\text { Large mitoribosomal subunit protein, possible } \\
\text { involvement in mitochondrial translation. }\end{array}$ & $16 \mathrm{~h}$ & 9.14 \\
\hline 15. YPEL3 & Yippee like 3 & Inhibitory effects in normal and tumor cell lines & $32 \mathrm{~h}$ & 9.08 \\
\hline 16. SMIM10L1 & Small integral membrane protein 10 like 1 & The function SMIM10L1 is not clear & $16 \mathrm{~h}$ & 8.13 \\
\hline 17. MYH14 & Myosin heavy chain 14 & Regulate the cytokinesis, motility and polarity cell & $28 \mathrm{~h}$ & 7.76 \\
\hline 18. EIF4A1 & Eukaryotic translation initiation factor $4 \mathrm{~A} 1$ & Proliferation and growth cell & $16 \mathrm{~h}$ & 7.38 \\
\hline 19. RPL37 & Ribosomal protein L37 & Component of the $60 \mathrm{~S}$ subunit & $16 \mathrm{~h}$ & 6.61 \\
\hline 20. UBALD1 & UBA like domain containing 1 & No characterized & $0 \mathrm{~h}$ & 6.6 \\
\hline
\end{tabular}

in cells with DNA damage and RPL26 inhibition, p53 protein levels do not increase (TAKAGI et al., 2005; CHEN \& KASTAN, 2010). During infection, alphaherpesviruses use anti-apoptotic strategies to maintain their replication and propagation (YOU et al., 2017). Therefore, it is possible that CaHV-1 uses the mechanism of RPL26 expression inhibition to complete its life cycle. Considering that, alpha herpes virus infections occurs lytic replication in epithelial cells before becoming latent in the trigeminal ganglion (COHRS\& GILDEN, 2016; LUECKE \& PALUDAN, 2015). Therefore, in MDCK cell, inhibitory process of RPL26 genic expression could ensure viral multiplication and complete viral cycle.

The ATP5G2 and MRPS17 genes down-regulation can be related to compromising mitochondrial function. BRÜGGEMANN et al. (2017), verified that ATP5G2 down-regulation reduced activity of the mitochondrial electron chain and this leads to reduced oxidative phosphorylation. The MRPS17 is required for the maintenance of respiratory-proficient mitochondria (HANLON et al., 2004). Some studies related the damage in this organelle by herpesvirus that induce shutoff of host functions, and contribute to the cell death and tissue damage (SAFFRAN et al., 2010; MURATA et al., 2000).

\section{COX2 expression validation by $R T-q P C R$}

Figure 1 shows the temporal evolution of PTGS2 (COX2) expression levels during infection, based on the RPKM values and relative quantification by RT-qPCR. Interestingly, both showed similar performance and a peak elevation at $32 \mathrm{~h}$ pi. Additionally, expression of COX2 during 
Table 2 - List of 20 most down-regulated genes during in vitro CaHV-1 infection as a function of time (H) and quantity (FC).

\begin{tabular}{|c|c|c|c|c|}
\hline Gene Symbol & Description & Encodes function protein & Time & $\mathrm{FC}$ \\
\hline 1. RPL26 & Ribosomal protein L26 & Cell proliferation & $24 \mathrm{~h}$ & -236.25 \\
\hline 2. ATP5G2 & $\begin{array}{l}\text { ATP synthase, } \mathrm{H}+\text { transporting, } \\
\text { mitochondrial F0 complex, subunitc- } 2\end{array}$ & $\begin{array}{l}\text { Mitochondrial ATP synthesis coupled proton } \\
\text { transport }\end{array}$ & $16 \mathrm{~h}$ & -99.11 \\
\hline 3. АТP5MC2 & ATP synthase membrane subunit c locus 2 & $\begin{array}{l}\text { Lipid binding and proton transmembrane } \\
\text { transporter activity }\end{array}$ & $4 \mathrm{~h}$ & -46.36 \\
\hline 4. TMED9 & Trans membrane p24 trafficking protein 9 & $\begin{array}{l}\text { Transport proteins located in the endoplasmic } \\
\text { reticulum and Golgi complex }\end{array}$ & $16 \mathrm{~h}$ & -38.05 \\
\hline 5. RPL23A & Ribosomal protein $\mathrm{L} 23 \mathrm{a}$ & Cell growth and regulation & oh & -35.08 \\
\hline 6. RPS27 & $\begin{array}{l}\text { Ribosomal protein S27 or metallopan- } \\
\text { stimulin } 1 \text { (MPS-1) }\end{array}$ & $\begin{array}{c}\text { Extra-ribosomal functions, regulate growth and } \\
\text { survival cell as well as DNA repair and } \\
\text { transcription }\end{array}$ & Oh & -26.26 \\
\hline 7. ARPC3 & Actin related protein $2 / 3$ complex subunit 3 & Control of actin polymerization in cells & $4 h$ & -24.84 \\
\hline 8. RPL29 & RPL29 ribosomal protein L29 & Cell proliferation & $16 \mathrm{~h}$ & -24.54 \\
\hline 9. $\mathrm{S} 100 \mathrm{~A} 2$ & S100 calcium binding protein $\mathrm{A} 2$ & Cell regulation & $16 \mathrm{~h}$ & -19.79 \\
\hline 10. CRYAB & Crystallin alpha B & Apoptosis inhibition & Oh & -15.40 \\
\hline 11. EEF1A1 & Eukaryotice longation factor 1 alpha & $\begin{array}{l}\text { Instead to upregulation, the down regulation of } \\
\text { eEF1A1, is required for the apoptosis }\end{array}$ & $4 \mathrm{~h}$ & -14.12 \\
\hline 12. TMEM97 & Transmembrane protein 97 & Cell proliferation & $16 \mathrm{~h}$ & -12.94 \\
\hline 13. DLADRA & MHC class II DR alpha chain & Cellular immunity & $28 \mathrm{~h}$ & -12.26 \\
\hline 14. MRPS17 & Mitochondrial ribosomal protein S17 & Mitochondrial proteins synthesis & $4 \mathrm{~h}$ & -11.17 \\
\hline 15. DHRS2 & Dehydrogenase/reductase2 & Cycle cell regulation and apoptosis & $28 \mathrm{~h}$ & -10.95 \\
\hline 16. MMP13 & Matrix metallopeptidase 13 & Cell proliferation & $4 \mathrm{~h}$ & -10.68 \\
\hline 17. KRT14 & Keratin 14 & $\begin{array}{l}\text { Structural molecule activity and keratin filament } \\
\text { binding }\end{array}$ & Oh & -10.65 \\
\hline 18. SMIM7 & Small integral membrane protein 7 & Integral component membrane & $4 \mathrm{~h}$ & -10.39 \\
\hline 19. TMEM179B & Transmembrane protein 179B & Membrane protein transporter & Oh & -9.71 \\
\hline 20. CCL17 & $\mathrm{C}-\mathrm{C}$ motif chemokine ligand 17 & $\begin{array}{l}\text { Mediating by chemotaxis the infiltration of } \\
\text { Th2 cells in inflammatory reaction }\end{array}$ & $4 \mathrm{~h}$ & -9.69 \\
\hline
\end{tabular}

CaHV-1 infection has been analyzed by comparing the FC values obtained with RNA-seq and RT-qPCR (Figure 2). The comparison performed between RNA-seq and RT-qPCR reveals a correlation between both techniques used for the quantification of COX2 expression level. Thus, it was verified that the RNAseq technique can be reliable for the quantification of gene expression, and it was possible to confirm the increase in COX2 expression level.

In cells infected with PRV, the highest level of COX2 transcription occurred at $8 \mathrm{~h}$ pi, showing a 11-fold elevation (RAY et al., 2004). In HSV-1-infected cells, the transcription of COX2 mRNA reached a fold-change peak of 14.5 at $8 \mathrm{~h}$ pi (LIU et al., 2014). However, in CaHV-1 infection, the onset of COX2 elevation occurred $16 \mathrm{~h}$ pi with $\mathrm{FC}=2.54 \pm 0.16$ (RT-qPCR) and $1.51 \pm 0.32$ (RNA-seq). The peak of COX2 expression in CaHV-1 infection was observed later in relation to PRV and HSV-1 infection, reaching maximum levels $32 \mathrm{~h}$ pi with FC values of $25.40 \pm 2.37$ (RT-qPCR) and $26.41 \pm 3.27$ (RNA-seq). These different expression patterns might occur due to infection cycle of CaHV-1 be longer than those exhibited by PRV and HSV-1. During in vitro PRV infection, the cytopathic effects occurs at $16 \mathrm{~h}$ pi (PASDELOUP et al., 2013). In this study, virus isolate presents onset of cytopathic effect at $20 \mathrm{~h}$ post inoculation and evidenced at $24 \mathrm{~h}$ pi (data not shown). Additionally, LARA and colleagues (2016) observed late cytopathic effects during $\mathrm{CaHV}-1$ infection after $48 \mathrm{~h}$ pi, while DE PALMA et al. (2010) at $72 \mathrm{~h}$ pi.

Hypoxia Response (GO: 0001666) was among the biological processes related to COX2 expression. Hypoxia inducible factors (HIFs) modulate the gene expression of DNA viruses, such as herpesviruses, due to the presence of elements responsive to hypoxia in their promoters, which increase viral replication (TOMASKOVA 


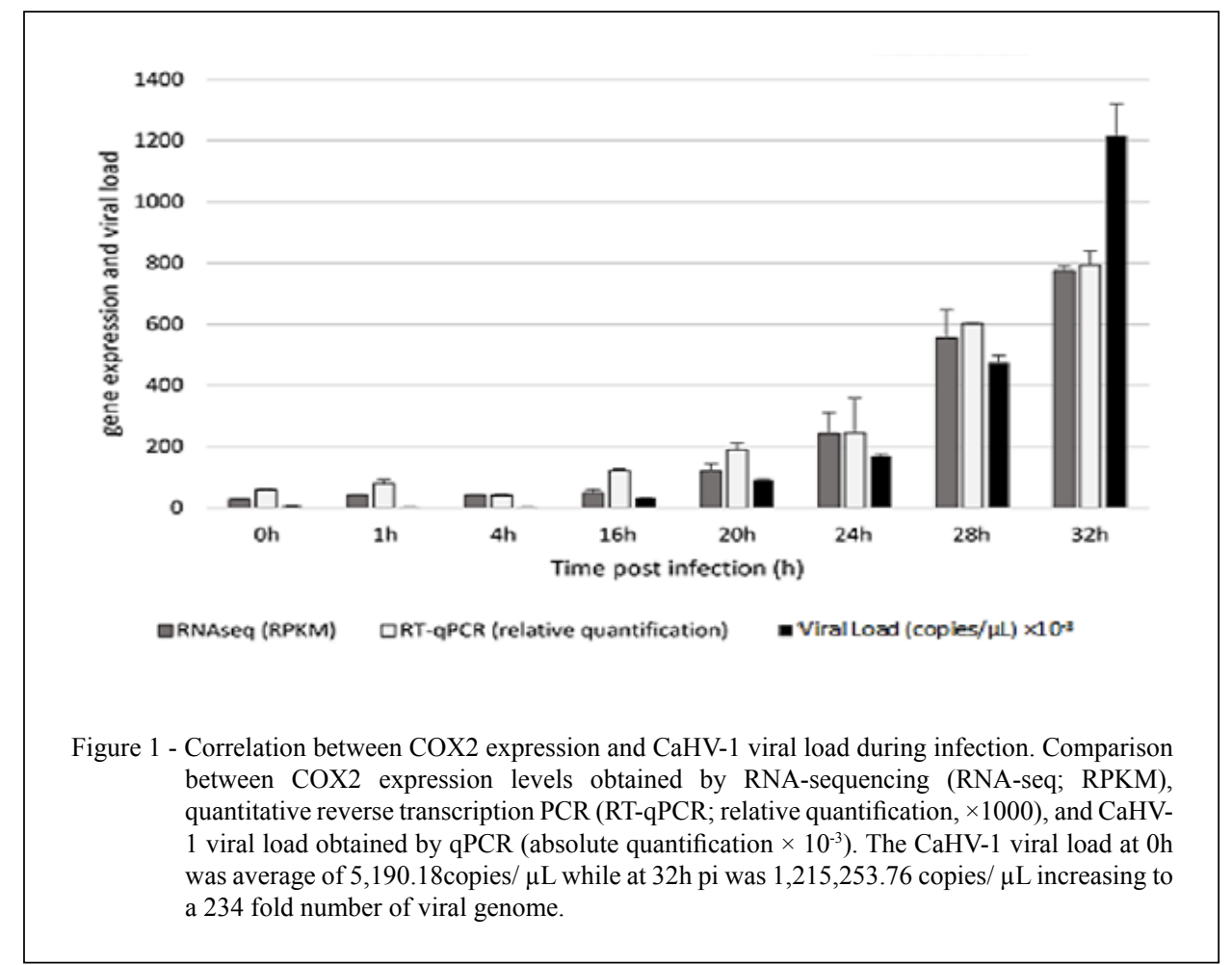

et al., 2011). High COX2 expression levels occur during inflammation, and oxygen levels decrease, thus leading to the activation of adaptive responses related to the expression of HIFs via nitric oxide (CARIA et al., 2014). In addition, hypoxia promotes vessel growth through the positive regulation of several pro-angiogenic pathways (KROCK et al., 2013). Interestingly, angiogenesis has been linked to elevated COX2 levels due to the increase of the levels of associated pro-angiogenic growth factors (YAO et al., 2011). Our gene ontology analysis confirmed the presence of the biological process Regulation of angiogenesis (GO: 0045765), among the up-regulated genes. Therefore, hypoxia, DNA damage response, and apoptosis may indicate the occurrence of viral replication and consequent increase in COX2 levels. Gene expression levels associated with hypoxia-related genes, with the exception of COX2, remained constant after their detection $(24 \mathrm{~h}$ pi). However, levels of other genes related to $\mathrm{COX} 2$ increased $32 \mathrm{~h}$ pi, indicating that COX2 possibly interacts or activates other genes that promote other cellular biological processes. Thus, gene ontology analysis of the positively regulated genes revealed that when the $\mathrm{FC}$ value of $\mathrm{COX} 2$ increased, the number of biological processes that were involved with the gene increased as well (Figure 3). Absolute viral load quantification and COX2 gene
expression

Viral load during infection was measured by $\mathrm{qPCR}$ and correlated to COX2 expression by RT-qPCR (relative quantification) and RNA-seq (RPKM). Interestingly, both viral load and COX2 expression increased during the evolution of the infection, with the onset occurring $20 \mathrm{~h}$ pi. Considering pre-inoculation COX2 levels as basal values, it may be suggested that viral replication is involved in the induction of COX2 expression. Moreover, the highest viral load $\left(\sim 1.62 \times 10^{6}\right.$ copies $\left./ \mu \mathrm{L}\right)$ was reached $32 \mathrm{~h}$ pi, which is when the expression level of COX2 also reached its maximum (Figure 1). The increase in both COX2 expression and viral load throughout the viral infection time can indicate a correlation between the two parameters.

COX2 transcripts are important for viral replication and virus-host interaction (RAY et al., 2004; REINOLDS \& ENQUIST, 2006). Thus, herpesviruses exploit the induction of the COX2 cellular pathway for viral replication (CHENG et al., 2015). Therefore, the increase in COX2 transcription reported in this study was verified in infections by other herpesviruses, including bovine alphaherpesvirus 4 (BoHV-4), human herpesvirus 4 [HHV-4, also known as Epstein- 


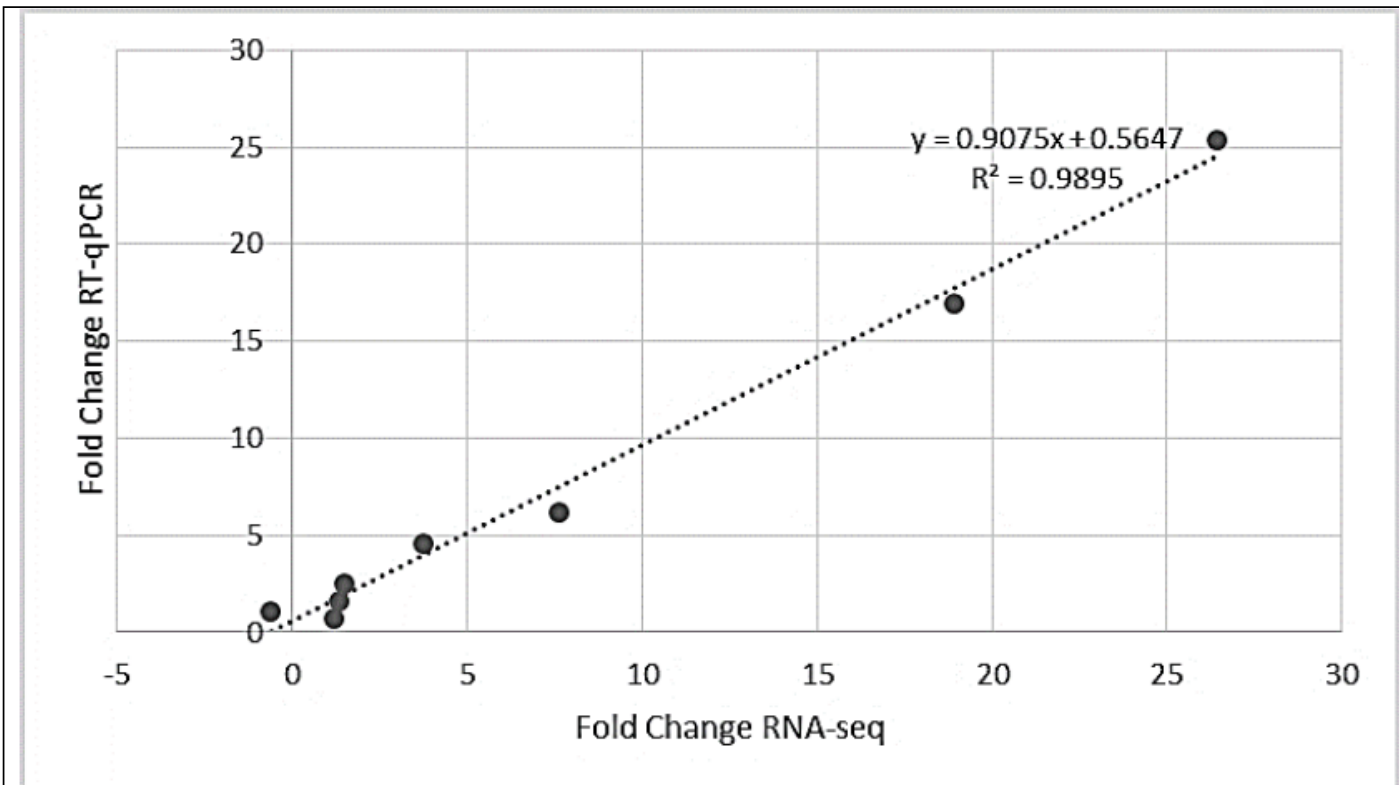

Figure 2 - Correlation of the fold-change values of COX2 expression. The values were obtained from RNA-sequencing (RNA-seq) and quantitative reverse transcription PCR (RT-qPCR).

Barr virus (EBV)], human herpesvirus 6 (HHV-6), HSV-1, and Kaposi's sarcoma-associated herpesvirus (KSHV) (JANELLE et al., 2002; DONOFRIO et al., 2007; SHARMA-WALIA et al., 2010; AL-SALAM et al.2013; LIU et al., 2014). The role of COX2 in the viral replication cycle is unclear (REINOLDS \& ENQUIST, 2006). However, in HHV-6, viral gene transcription is required for COX2 promoter activation (JANELLE et al., 2002). In cytomegalovirus infections, blockage of COX2 inhibited the viral mRNA by interrupting protein and DNA synthesis (ZHU et al., 2002). The increase in COX2 expression can lead to the enhanced production of prostaglandin (PG), which is an important factor in the inflammatory cascade reaction (LIU et al., 2014). The rise in prostaglandin levels was associated to latent herpesvirus activation (BAKER et al., 1985). In contrast, previous studies indicated that the PGs act as inhibitors of replication in some negative-strand RNA viruses such as the Sendai (SeV), Mayaro (MAYV) and polivirus (SANTORO et al., 1983; CONTI et al., 1996; BARBOSA \& RABELLO, 1998). In these viruses, the PGs can affect an early and a late phase of viral production, including the synthesis and/or maturation of viral proteins (SANTORO et al., 1994).

COX2 inhibitors have been tested for the treatment of the infection and, interestingly, have proven efficient in reducing the frequency and severity of the lesions (CHENG et al., 2015). Moreover, use of selective COX2 inhibitors may favor interferon responses during infections, and increase antiviral immunity (KIRKBY et al., 2011). Considering the availability of drugs that selectively inhibit the COX2 pathway, further studies to assess their therapeutic potential for use against $\mathrm{CaHV}-1$ infections are needed. However, these results may serve for as a basis for future studies on the use of selective COX2 inhibitors for the suppression of $\mathrm{CaHV}-1$ replication in active infection states.

\section{CONCLUSION}

In summary, RNA-seq allowed for the transcriptomic analysis of differentially expressed genes in host cell in vitro, during CaHV-1 infection. COX2 (i.e., PTGS2) expression from infected cells was among the most induced. High expression levels of this gene were related to replication and viral load enhancement during CaHV-1 infection. In contrast, RPL26 was the most inhibited gene, possibly because of apoptosis inhibition, which contributed to viral infection in the host cells.

Therefore, the findings verified in this study can contribute to determining important targets for inhibiting or preventing canine herpesvirus infection either by cellular or viral mechanisms and lessening clinical signs and mortality during disease outbreaks. 


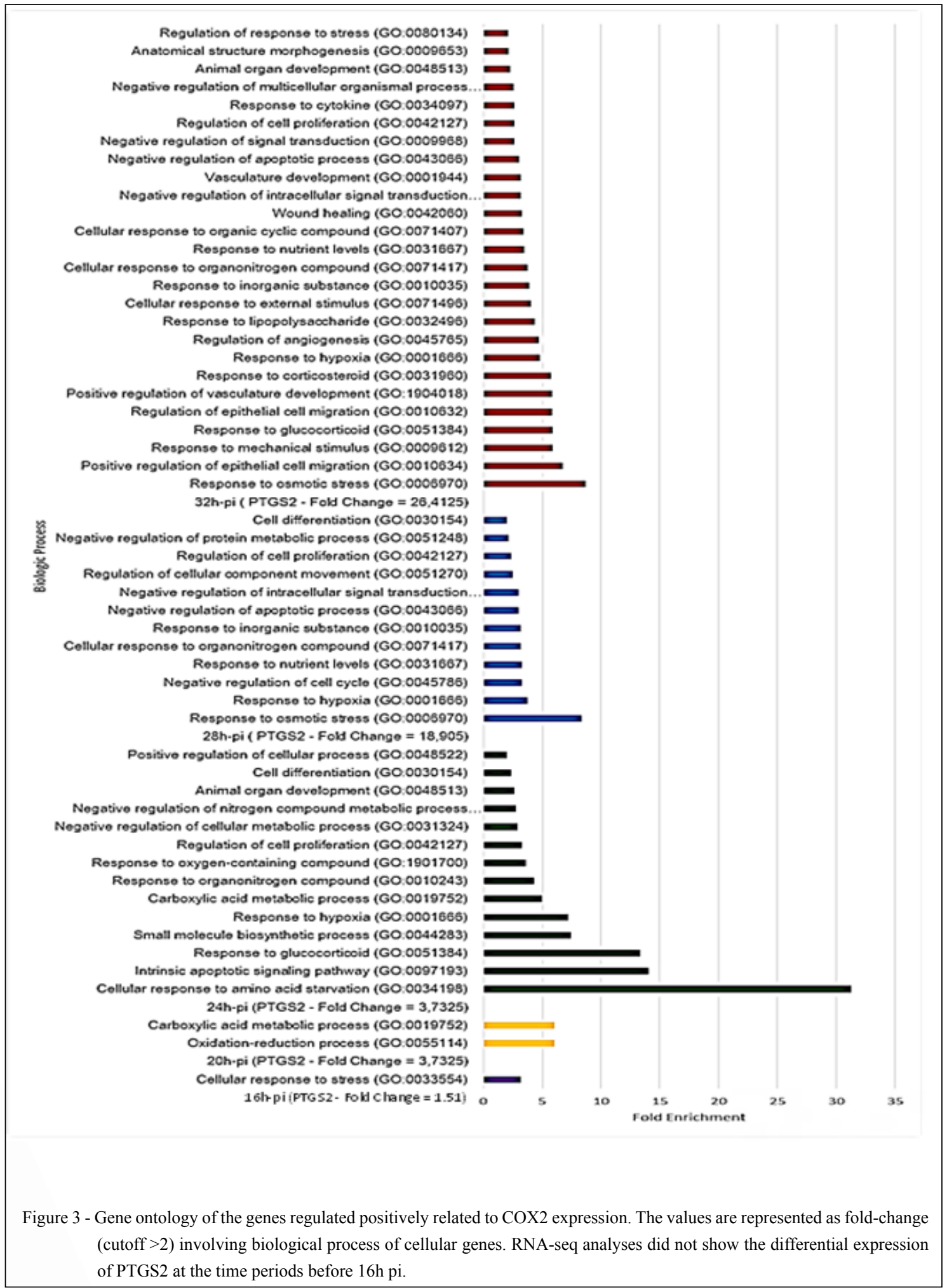

Ciência Rural, v.48, n.10, 2018. 


\section{ACKNOWLEDGMENTS}

This study was financed in part by Coordenação de Aperfeiçoamento de Pessoal de Nível Superior (CAPES) - Finance Code 001 and Fundação do Instituto de Biociências (FUNDIBIO) of Universidade Estadual Paulista (UNESP) Campus Botucatu.

\section{BIOETHICS AND BIOSSECURITY COMMITTEE APPROVAL}

The experimental design was approved by the local Ethics Committee for the Use of Animals (CEUA) of the UNESP, under the protocol number 141/2016, in accordance with the standards of the National Council for the Control of Animal Experimentation (CONCEA).

\section{DECLARATION OF CONFLICTING INTERESTS}

The authors declare no conflict of interest. The founding sponsors had no role in the design of the study; in the collection, analyses, or interpretation of data; in the writing of the manuscript, and in the decision to publish the results.

\section{AUTHORS' CONTRIBUTIONS}

The authors contributed equally to manuscript.

\section{REFERENCES}

AL-SALAM, S. et al. Epstein-Barr virus infection correlates with the expression of COX-2, p16 $6^{\mathrm{INK} 4 \mathrm{~A}}$ and $\mathrm{p} 53$ in classic Hodgkin lymphoma. International Journal of Clinical \& Experimental Pathology, v.6, p. 2765-2777, 2013. Available from: <https://www.ncbi.nlm.nih.gov/ pmc/articles/PMC3843257/>. Accessed: Jul. 07, 2017.

BAHRAMI, S.; DRABLØS, F. Gene regulation in the immediateearly response process. Advances in Biological Regulation, v.62, n.7491, p.37-49, 2016. Available from: $<$ https://www.ncbi.nlm.nih gov/pubmed/27220739>. Accessed: May 02, 2018. doi: 10.1016/j. jbior.2016.05.001.

BAKER, D.A.; THOMAS, J.The effect of prostaglandin E2 on the initial immune response to herpes simplex virus infection. American Journal of Obsetric \& Ginecology, v.151, n.5, p.586-90, 1985. Available from: $<$ https://www.ajog.org/article/0002-9378(85)90144-9/ pdf $>$. Accessed: May 08, 2018. doi: 10.1016/0002-9378 (85)90144-9.

BARBOSA, J.A.; RABELLO, A. M. Inhibition of Mayaro virus replication by prostaglandin $\mathrm{A}_{1}$ in Aedes albopictus cells. Revista de Microbiologia, v.29, n.3, 1998. Available from: < http://dx.doi. org/10.1590/S0001-37141998000300013>. Accessed: Mar. 02, 2018. doi: 10.1590/S0001-37141998000300013.

BRÜGGEMANN, M. et al. Analysis of the expression of the mitochondrial atp synthase (complex v) subunits in clear cell renal cell carcinoma. Translational Oncology, v.10, n.4, p.661668, 2017. Available from: <https://www.ncbi.nlm.nih.gov/pmc/ articles/PMC5496479/>. Accessed: Apr. 15, 2018. doi: 10.1016/j. tranon. 2017.06.002.

CARIA, C. R.P., et al. Nitric oxide interferes with hypoxia signaling during colonic inflammation. Arquivos de Gastroenterologia, v.51, n.4, p. 302-308, 2014. Available from: <http://www.scielo.br/ pdf/ag/v51n4/0004-2803-ag-51-04-302.pdf>. Accessed: Dec. 12, 2018. doi: 10.1590/S0004-28032014000400007.

CARMICHAEL, L.E; GREENE, C.E. Canine herpesvirus infection. In: Greene C.E. (Eds.) Infectious Diseases of the Dog and Cat, Philadelphia: WB Saunders, 2012. Cap.5, p.54.

CHEN, J.; KASTAN, M.B. 5'-3'-UTR interactions regulate p53 mRNA translation and provide a target for modulating $\mathrm{p} 53$ induction after DNA damage. Genes \& Development, v.24, p.2146-2156, 2010. Available from: $<$ http://genesdev.cshlp.org/content/24/19/2146.long>. Accessed: July 02, 2017. doi: 10.1101/gad.1968910.

CHEN, C. et al. Regulation of cellular and viral protein expression by the Epstein-Barr virus transcriptional regulator Zta Implications for therapy of EBV associated tumors. Cancer Biology \& Therapy, v.8, n.11, p. 987-995, 2009.

CHENG, J. et al. Celecoxib inhibits the lytic activation of Kaposi's sarcoma-associated herpesvirus through down-regulation of RTA expression by inhibiting the activation of p38 MAPK. Viruses, v.7, p. 2268-2287, 2015. Available from: <http://doi.org/10.3390/ v7052268>. Accessed: Jun. 05, 2017. doi: 10.3390/ v7052268.

CLEMENTE, M. et al. Different role of COX2 and angiogenesis in canine inflammatory and non-inflammatory mammary cancer. The Veterinary Journal, v.197, p. 427-432, 2013. Available from: <https://doi.org/10.1016/j.tvj1.2013.02.009>. Accessed: May 28, 2017. doi: $10.1016 /$ j.tvj1.2013.02.009.

CONTI, C. et al. Inhibition of Poliovirus replication by Prostaglandins $\mathrm{A}$ and $\mathrm{J}$ in human cells. Antimicrobial Agents and Chemotherapy, v.40, n.2, p.367-372, 1996. Available from: $<$ https://www.ncbi.nlm.nih.gov/pmc/articles/PMC163118/>. Accessed: Mar. 02, 2018.

COHRS, R. J.; GILDEN, D. Colorado alphaherpesvirus latency society symposium. Journal of Neurovirology, v. 22, n.5, p. 703-714, 2016. Available from: $<$ http://doi. org/10.1007/s13365-016-0468-x $>$.

DAVISON, A.J. et al. The Order Herpesvirales. Archives of Virology, v. 154, n. 1, p.171-177, 2009.Available from: <https:// www.ncbi.nlm.nih.gov/pmc/articles/PMC3552636/>. Accessed: Oct. 10, 2017. doi: 10.1007/s00705-008-0278-4.

DE PALMA, V. E. et al. An atypical clinical presentation for the first isolation of Canid herpesvirus 1 in Argentina. Arquivo Brasileiro de Medicina Veterinária e Zootecnia, v.62, n.5, p.1267-1270, 2010. Available from: <http://dx.doi.org/10.1590/ S0102-09352010000500034>. Accessed: Mar. 18, 2018.

DONOFRIO, G. et al. Bovine herpesvirus 4 (BoHV-4) is tropic for bovine endometrial cells and modulates endocrine function. Reproduction, v.134, n.1, p.183-197, 2007. Available from: $<$ https://www.ncbi.nlm.nih.gov/pmc/articles/PMC2740819/>. Accessed: Sep. 04, 2017. doi: 10.1530/ REP-07-0065.

EVERAERT, C. et al. Benchmarking of RNA-sequencing analysis workflows using whole-transcriptome RT-qPCR expression data. Scientific Reports, v.7, 1559, 2017. Available from: <https://www. ncbi.nlm.nih.gov/pmc/articles/PMC5431503/>. Accessed: Nov. 05, 2017. doi: 10.1038/ s41598-017-01617-3.

EVERMANN, J.F. et al. Canine Reproductive, Respiratory, and Ocular Diseases due to Canine Herpesvirus. Veterinary Clinics of 
North America: Small Animal Practice, v.41, n.6, p. 1097-1120, 2011. ISSN 0195-5616. Available from: <https://doi.org/10.1016/j. cvsm.2011.08.007>. Accessed: Nov. 27, 2016. doi: 10.1016/j. cvsm.2011.08.007

FLEMINGTON, E. K. Herpesvirus Lytic Replication and the Cell Cycle: Arresting New Developments. Journal of Virology, v. 75, n. 10 , p. $4475-4481,2001$. Available from: <http://jvi.asm.org/ content/75/10/4475.full $>$. Accessed: Mar. 10, 2017. doi: 10.1128/ JVI.75.10.4475-4481.2001.

FLORES, E.F.; KREUTZ, L.C. Multiplicação dos vírus. In: Flores, E.F. (Eds.), Virologia Veterinária, Santa Maria: Editora UFSM, 2012, Cap. 5, p.113-143.

GALE JR., M. et al. Translational Control of Viral Gene Expression in Eukaryotes. Microbiology and Molecular Biology, v.64, n. 2, p.239-280, 2000.Available from: <http://mmbr.asm org/content/64/2/239.long >. Accessed: Jul. 09, 2017. doi:10.1128/ MMBR.64.2.239-280.2000.

HANLON, S.E. et al. Analysis of the meiotic role of mitochondrial ribosomal proteins MRPS17 and MRPL37 in Saccharomyces cerevisiae. Yeast, v.21, n. 15, p. 1241-1252, 2004. Available from: $<$ https://onlinelibrary.wiley.com/doi/abs/10.1002/yea.1174>. Accessed: Mar. 03, 2018. doi: 10.1002/ yea. 1174.

HOULDCROFT, C. J.; BREUER, J. Tales from the crypt and coral reef: the successes and challenges of identifying new herpesviruses using metagenomics. Frontiers in Microbiology, v.6, 188, 2015. Available from: <https://www.ncbi.nlm.nih.gov/pmc/ articles/PMC4358218/>. Accessed: Nov. 11, 2017. doi: 10.3389/ fmicb.2015.00188.

ICTV 2017. International Comittee on Taxonomy of Viruses. Virus Taxonomy: 2017 Release. Available from: $<$ https://talk.ictvonline. org/taxonomy/>. Accessed: May 10, 2018.

JANELLE, M-E.et al. Activation of monocyte Cyclooxygenase-2 gene expression by Human Herpesvirus 6. The Journal of Biological Chemistry, v.277, n.34, p. 30665-30674, 2002. Available from: <http://www.jbc.org/content/277/34/30665.long $>$. Accessed: Jul. 26, 2017. doi: 10.1074/bc. 203041200.

JURAK, I. et al. Mammalian alphaherpesvirus miRNAs. Biochimica et Biophysica Acta, v.1809, n.11-12, p.641-653, 2011. Available from: <https://www.ncbi.nlm.nih.gov/pmc/ articles/PMC3382970/>. Accessed: May 08, 2017. doi: 10.1016/j. bbagrm.2011.06.010.

KAL, A. J. et al. Dynamics of gene expression revealed by comparison of serial analysis of gene expression transcript profiles from yeast grown on two different carbon sources. Molecular Biology of the Cell, v.10, n.6, p.1859-1872, 1999. Available from: <https://www.ncbi.nlm.nih.gov/pmc/articles/PMC25383/>. Accessed: May 02, 2018.

KASTAN, M.B.; BARTEK, J., 2004.Cell-cycle checkpoints and cancer. Nature, v. 432, p. 316-328, 2004. Available from: <http:// dx.doi.org/10.1038/nature03097>. Accessed: Jul. 02, 2017. doi: 10.1038/nature03097.

KIRKBY, N. et al. Differential COX2 induction by viral and bacterial PAMPs: Consequences for cytokine and interferon responses and implications for anti-viral COX2 directed therapies. Biochemical and Biophysical Research Communications, v.438, n.2, p. 249-256, 2011. Available from: <https://www.ncbi. nlm.nih.gov/pmc/articles/PMC3759847/>. Accessed: July 27, 2017. doi: 10.1016/j.bbrc.2013.07.006.

KROCK, B.L.et al. Hypoxia-induced angiogenesis: good and evil. Genes \& Cancer, v.2, n.12, p. 1117-1133, 2013. Available from: $<$ https://www.ncbi.nlm.nih.gov/pmc/articles/PMC3411127/>. Accessed: Feb. 03, 2017. doi: 10.1177/1947601911423654.

KUNZMANN, A. et al. PTGS2 (Cyclooxygenase-2) Expression and Survival among Colorectal Cancer Patients: A Systematic Review. Cancer Epidemiology Biomarkers \& Prevention, v.22, n. 9, 2013. Available from: <http://cebp.aacrjournals. org/content/22/9/1490.long $>$. Accessed: Jul. 27, 2017. doi: 0.1158/1055-9965.EPI-13-0263.

LAN, X. et al. Integrated host and viral transcriptome analyses reveal pathology and inflammatory response mechanisms to ALV-J injection in SPF chickens. Scientific Reports, v. 7, n.46156. Available from: <https://www.ncbi.nlm.nih.gov/pmc/ articles/PMC5388866/>. Accessed: May 02, 2018. doi: 10.1038/ srep46156.

LARA, E.G.V. et al. Pathology Isolation and Identification of Canine Herpesvirus (CHV-1) in Mexico. Open Journal of Pathology, v.6, p.111-112, 2016. Available from: <http://dx.doi. org/0.4236/ojpathology.2016.63014>. Accessed: Aug. 01, 2017. doi: 10.4236/ojpathology.2016.63014.

LARIONOV, A. et al. 2005. A standard curve based method for relative real time PCR data processing. BMC Bioinformatics, v. 6, n.62, p. 1-16, 2005. Available from: $<$ https://bmcbioinformatics. biomedcentral.com/articles/10.1186/1471-2105-6-62>. Accessed: May 31, 2017. doi: 10.1186/1471-2105-6-62.

LARSEN, R. W. et al. Prevalence of canid herpesvirus- 1 infection in stillborn and dead neonatal puppies in Denmark. Acta Veterinaria Scandinavica, v. 57, n. 1, 1, 2015. Available from: <https://www. ncbi.nlm.nih.gov/pmc/articles/PMC4296690/>. Accessed: Sep. 20, 2016. doi: 10.1186/ s13028-014-0092-9.

LUECKE, S.; PALUDAN, S.R. Chapter Two - Innate Recognition of Alphaherpesvirus DNA, Editor: Karl Maramorosch, Thomas C. Mettenleiter. Advances in Virus Research, Academic Press, v. 92, p. 63-100, 2015. Available from: <http://www.sciencedirect. com/science/article/pii/S0065352714000104>. Accessed: Jun. 10, 2018. doi: 10.1016/bs.aivir.2014.11.003.

LIU, Y. et al. The role of cyclooxygenase in multiplication and reactivation of HSV-1 in vestibular ganglion neurons. The Scientific World Journal, v. 2014, 912640, 2014. Available from: <https://www.hindawi.com/journals/tswj/2014/912640/>. Accessed: Mar. 19, 2017.doi: 10.1155/ 2014/ 912640.

LIVAK, K.; SCHIMITTGEN, T.D. Analysis of relative gene expression data using real-time quantitative PCR and the $2^{-\Delta \Delta C T}$ Method. Methods, v.25, p. 402-408, 2001. Available from: <http:/ www.gene-quantification.net/livak-2001.pdf $>$. Accessed: Jun. 13, 2017. doi: $10.1006 /$ meth. 2001. 1262

MALONE, E.K. et al. Disseminated canine herpesvirus-1 infection in an immunocompromised adult dog. Journal of Veterinary Internal Medicine, v.24, n. 4, p. 965-968, 2010. Available from: $<$ https://onlinelibrary.wiley.com/doi/abs/10.1 111/j.1939-1676.2010.0512.x>. Accessed: Mar. 11, 2017. doi: 10.1111/j.1939-1676.2010.0512.x. 
MURATA, T. et al. Mitochondrial distribution and function in herpes simplex virus-infected cells. Journal of General Virology, v. 81, 401-406, 2000. Available from: <http://jgv.Microbiology research. org/content/journal/jgv/10.1099/0022-1317-81-2-401\#tab2>. Accessed: Apr. 23, 2018. doi: 10.1099/0022-1317-81-2-401.

MUTZ, K.-O. et al. Transcriptome analysis using next-generation sequencing. Current Opinion in Biotechnology, v. 24, n.1, p. 22-30, 2013. doi: 10.1016/j.copbio.2012.09.004.

PARK, S.-J.et al. Selection of internal reference genes for normalization of quantitative reverse transcription polymerase chain reaction (qRT-PCR) analysis in the canine brain and other organs. Molecular Biotechnology, v.54, p.47-57, 2013. Available from: <https://doi.org/10.1007/s12033-012-9543-6>. Accessed: Jun. 13, 2017. doi: 10.1007/s12033-012-9543-6.

PASDELOUP, D. et al. Differing effects of herpes simplex virus 1 and pseudorabies virus infections on centrosomal function. Journal of Virology, v.87, v.12, p. 7102-7112, 2013. Available from: $<$ http://jvi.asm.org/content/87/12/7102.full $>$. Accessed: Apr. 10, 2017. doi:10.1128/JVI.00764-13.

PAULUS, C. et al. Transcriptome signature of virulent and attenuated pseudorabies virus-infected rodent brain. Journal of Virology, v.80, n.4, p.1773-1786, 2016. Available from: <http:// jvi.asm.org/ content/80/4/1773.full>. Accessed: Apr. 11, 2017. doi: 10.1128/JVI.80.4.1773-1786.2006

PRADO, P.T.C.; DEL BEL, E.A., 1998. C-fos, um gene de ativação imediata como marcador neural de nocicepção. Medicina (Ribeirão Preto Online), v.31, n.3, p.424-433, 1998. Available from: $<\mathrm{http} / /$ dx.doi.org/10.11606/issn.2176-7262.v.3i3p.424-433>. Accessed: May 04, 2017. doi: 10.11606/issn.2176-7262.

RAHAUS, M.; WOLFF, M. H. Reciprocal effects of Varicellazoster virus (VZV) and AP1: activation of jun, fos and ATF-2 after VZV infection and their importance for the regulation of viral genes. Virus Research, v. 92, n.1, p. 9-21, 2003. Available from: $<$ https://doi.org/10.1016/S0168-1702(02)00310-6>. Accessed: Jul. 20, 2017. doi: 10.1016/S0168-1702(02)00310-6.

RAY, N., ENQUIST, L.W., 2004. Transcriptional response of a common permissive cell type to infection by two diverse alphaherpesviruses. Journal of Virology, v.78, p. 3489-3501, 2004. Available from: <http://jvi.asm.org/content/78/7/3489.full>. Accessed: Jul. 22, 2017. doi: 10.1128/JVI.78.7.3489-3501.2004.

REINOLDS, A.E.; ENQUIST, L.W. Biological interactions between herpesviruses and cyclooxygenase enzymes. Reviews in Medical Virology, v.16, n.6, p. 393-403, 2006. Available from: $<$ https://doi.org/10.1002/rmv.519>. Accessed: Sep. 17, 2017. doi: $10.1002 / \mathrm{rmv} .519$.

ROBINSON, A.J. et al. Prevalence of serum antibodies to canine adenovirus and canine herpesvirus in the European red fox (Vulpesvulpes) in Australia. Australian Veterinary Journal, v. 83, p. 356-361, 2005. Available from: $<$ https://doi. org/10.1111/j.1751-0813.2005.tb15634.x>. Accessed: Aug. 05, 2017. doi: 10.1111/j.1751-0813.2005.tb15634.x.

ROBINSON, M.D.; SMYTH, G.K. Small-sample estimation of negative binomial dispersion, with applications to SAGE data Biostatistics, v. 9, n.2, p. 321-332, 2008. Available from: $<$ https:// doi.org/10.1093/biostatistics/kxm030>. Accessed: Nov. 18, 2017. doi: 10.1093/biostatistics/kxm030.
RONSSE, V. et al. Canine herpesvirus-1 (CHV-1): clinical, serological and virological patterns in breeding colonies. Theriogenology, v. 64, p. 61-74, 2005. Available from: <https:// doi.org/10.1016/j.theriogenology.2004.11.016>. Accessed: Mar. 03, 2016. doi: 10.1016/j.theriogenology.2004.11.016.

SAFFRAN, H.A. et al. Evidence for Translational regulation by the Herpes Simplex Virus Virion Host Shutoff Protein. Journal of Virology, v. 84, n.12, p. 6041-6049, 2010. Available from: <http:// jvi.asm.org/content/84/12/6041.full>. Accessed: Apr. 22, 2018. doi: 10.1128/JVI.01819-09.

SANTORO, M.G. et al. The relationship between prostaglandins and virus replication: Endogenous prostaglandin synthesis during infection and the effect of exogenous PGA on virus production in different cell lines and in persistently infected cells. Prostaglandins, v.25, n.3, p. 353-364, 1983. Available from: <http://www. sciencedirect.com/science/article/pii/0090698083900382>. Accessed: Apr. 05, 2018. doi: 10.1016/0090-6980(83)90038-2.

SANTORO, M.G. Heat shock proteins and virus replication: hsp70s as mediators of the antiviral effects of prostaglandins. Experientia, v.30, p.1039-1047, 1994. Available from: <https:// link.springer.com/article/10.1007/BF01923459>. Accessed: Apr. 05, 2018. doi: 10.1007/BF01923459.

SMILEY, J. R. (2004). Herpes Simplex Virus Virion host shutoff protein: immune evasion mediated by a viral RNAse? Journal of Virology, v.78, n.3, p.1063-1068. Available from: <http://jvi. asm.org/content/78/3/1063.full>. Accessed: May 06, 2018. doi: 10.1128/JVI.78.3.1063-1068.2004.

SCHULZE, C.; BAUMGÄRTNER, W. Nested polymerase chain reaction and in situ hybridization for diagnosis of canine herpesvirus infection in puppies. Veterinary Pathology, v.35, p. 209-217, 1998. Available from: <http://journals.sagepub.com/doi/ pdf/10.1177/030098589803500306>. Accessed: Dec. 15, 2015. doi: $10.1177 / 030098589803500306$.

SHARMA-WALIA, N. et al. Kaposi's sarcoma associated herpes virus (KSHV) induced COX2: a key factor in latency, inflammation, angiogenesis, cell survival and invasion. Plos Pathology, v. 12, n. 6, 2010. Available from: <https://www.ncbi.nlm.nih.gov/pmc/ articles/PMC2820536/>. Accessed: Apr. 18, 2018. doi: 10.1371/ journal.ppat.1000777.

TAKAGI, M. et al. Regulation of p53 Translation and Induction after DNA Damage by Ribosomal Protein L26 and Nucleolin. Cell, v.123, p. 49-63, 2005. Available from: <https://www.cell.com/cell/ fulltext/S0092-8674(05)00814-7>. Accessed: Mar. 12, 2018. doi: 10.1016/j.cell.2005.07.034

TINDALL, M. J.; CLERK, A. Modelling Negative feedback networks for Activating Transcription Factor 3 predicts a dominant role for miRNAs in Immediate early gene regulation. PLOS Computacional Biology, v.10, n.5, 2014, e1003597. Available from: <https://www.ncbi.nlm.nih.gov/pmc/articles/ PMC4014390/>. Accessed: May 04, 2018. doi: 10.1371/journal. pcbi.1003597.

TOMASKOVA, J. et al. Hypoxia induces the gene expression and extracellular transmission of persistent lymphocytic choriomeningitis virus. Journal of Virology, v.85, n.24, p.13069-13076, 2011. Available from: <http://jvi.asm.org/ content/85/24/13069.full>. Accessed: Dec. 17, 2016. doi: 10.1128/ JVI.00829-11. 
WANG, Z. et al. RNA-Seq: a revolutionary tool for transcriptomics. Nature Reviews Genetics, v.10, n.1, p. 57-63, 2009. Available from: <http://doi.org/10.1038/nrg2484>. Accessed: Jan. 13, 2017. doi: $10.1038 / \mathrm{nrg} 2484$.

WEI, F. et al. Cell Cycle Regulatory Functions of the KSHV Oncoprotein LANA. Frontiers in Microbiology, v.7, n. 334, 2016. Available from: $\quad<$ https://www.ncbi.nlm.nih.gov/pmc/articles/PMC4811921/>. Accessed: Jun. 05, 2017. doi: 10.3389/fmicb.2016.00334.

YANG, I.S.; KIM, S. Analysis of whole transcriptome sequencing data: workflow and software. Genomics \& Informatics, n. 13, v. 4, p.119-125, 2015. Available from: <https://www.ncbi.nlm.nih. gov/pmc/articles/PMC4742321/>. Accessed: Jul. 05, 2017. doi: 10.5808/GI.2015.13.4.119.

YAO, L. et al. The function and mechanism of COX-2 in angiogenesis of gastric cancer cells. Journal of Experimental \& Clinical Cancer Research, v.30, p. 1-13, 2011. Available from:
<https://www.ncbi.nlm.nih.gov/pmc/articles/PMC3039621/>. Accessed: Jul. 10, 2017. doi: 10.1186/ 1756-9966-30-13

YOU, Y. et al. The suppression of apoptosis by $\alpha$-herpesvirus. Cell Death \& Disease, v.8, n.4, 2017. Available from: <https://www. ncbi.nlm.nih.gov/pmc/articles/PMC5477576/>. Accessed: Jan. 12, 2018. doi: 10.1038/cddis.2017.139.

ZHANGA, C. et al. Transcriptional activation of the human stressinducible transcriptional repressor ATF3 gene promoter by p53. Biochemical and Biophysical Research Communications, v.297, p. 1302-1310, 2002. Available from: <http://www.sciencedirect. com/science/article/pii/S0006291X02023823>. Accessed: Apr. 14, 2018. doi: 10.1016/S0006-291X(02)02382-3.

ZHU, H. et al. Inhibition of cyclooxygenase 2 blocks human cytomegalovirus replication. Proceedings of the National Academy of Sciences, v.99, n. 6, p. 3932-3937, 2002. Available from: <http://www. pnas.org/content/99/6/3932>. Accessed: Oct.02, 2017. doi: 10.1073/ pnas.052713799. 